\title{
ANALISIS PENYEBAB RISIKO PRODUKSI JAMUR SHIITAKE (Lentinus edodes) DI PT. INTI JAMUR RAYA, DESA CIKOLE, KECAMATAN LEMBANG KABUPATEN BANDUNG BARAT
}

\section{Kuswarini Kusno dan Jesica Ferina Tarigan}

Fakultas Pertanian, Universitas Padjadjaran

Email: kuswarini.kusno@unpad.ac.id

\begin{abstract}
ABSTRAK
Produktivitas sayuran jamur berkembang pesat di Indonesia. Salah satu perusahaan yang memproduksi jamur adalah PT. Inti Jamur Raya yang komoditas utamanya adalah jamur shiitake. Perusahaan melakukan budidaya jamur dengan menggunakan baglog. Selama tahun 2015-2016, produktivitas jamur shiitakenya mengalami fluktuasi dan tidak mencapai tingkat produktivitas yang ditargetkan perusahaan. Karena itu, perlu diketahui penyebab dari fluktuasi produktivitas jamur shiitake tersebut. Tujuan penelitian ini adalah mengidentifikasi penyebab risiko produksi jamur shiitake di PT. Inti Jamur Raya. Untuk mencapai tujuan tersebut, dilakukan analisis deskriptif berdasarkan risiko produksi yang terjadi pada setiap tahapan produksi, kemudian dilakukan evaluasi terhadap penyebab risiko yang teridentifikasi dengan metode Failure Mode and Effect Analysis (FMEA). Hasil penelitian menunjukkan bahwa dari 22 penyebab yang teridentifikasi, terdapat 9 penyebab prioritas risiko, yaitu: 1) baglog terkena penyakit Trichoderma spp; 2) baglog terkena penyakit Neurospora spp; 3) baglog terkena penyakit Penicillium spp; 4) baglog terkena penyakit Mucor spp; 5) baglog tidak ditutup rapat; 6) baglog yang terkena penyakit tidak dibuang; 7) baglog terlambat dibuka; 8) cuaca ekstrim; dan 9) penyiraman yang tidak teratur.
\end{abstract}

Kata kunci: jamur shiitake, risiko produksi, FMEA

\begin{abstract}
The productivity of mushroom vegetables is growing rapidly in Indonesia. One of the companies that produce mushrooms is PT. Inti Jamur Raya which its main commodity is shiitake mushroom. The company plant mushrooms by using baglog. During 2015-2016, the productivity of shiitake mushrooms was fluctuative and did not reach the level of productivity targeted by the company. Therefore, it is necessary to know the cause of the fluctuations. The purpose of this study was to identify the cause of the risk of shiitake mushroom production at PT. Inti Jamur Raya. To achieve the objectives, the data were analyzed descriptively based on production risk occurring at each stage of production, then the identified causes were evaluated with Failure Mode and Effect Analysis (FMEA). The results showed that of the 22 causes identified, there were 9 priority causes of risk, namely: 1) baglog affected by Trichoderma spp. desease; 2) baglog affected by Neurospora spp. desease; 3) baglog affected by Penicillium spp. desease; 4) baglog affected by Mucor spp. desease; 5) baglog was not tightly sealed; 6) the baglog affected by the disease was not discarded; 7) baglog late opened; 8) extreme weather; and 9) the watering time was not well-scheduled.
\end{abstract}

Keywords: shiitake mushroom, production risk, FMEA 


\section{PENDAHULUAN}

Hortikultura merupakan salah satu sub sektor pertanian yang berpotensi besar untuk dikembangkan. Terlebih letak Indonesia yang berada di garis khatulistiwa sangat menguntungkan bagi perkembangan hortikultura (Bustaman, 2015). Ketersediaan berbagai jenis tanaman hortikultura, yang meliputi buah-buahan, sayuran, tanaman hias dan tanaman obat menjadikan komoditas hortikultura memiliki prospek pengembangan yang sangat baik karena memiliki nilai ekonomis serta potensi pasar yang terbuka lebar baik di dalam negeri maupun di luar negeri.

Kontribusi seluruh komoditas hortikultura terhadap PDB Indonesia pada tahun 2011-2013 tiap tahunnya mengalami peningkatan terutama pada komoditas sayuran (Ditjen Hortikultura, 2014). Selain itu dilihat dari pertumbuhan PDB sayuran, komoditas ini memiliki angka yang paling besar dibandingkan dengan komoditas lainnya.

Dilihat dari produktivitas beberapa jenis tanaman sayuran di Indonesia, perkembangan yang cukup pesat ditunjukkan oleh sayuran jamur (BPS, 2015). Jamur sebagai salah satu komoditas sayuran unggulan, memiliki kandungan gizi dan potensi yang tinggi sebagai bahan makanan dan bahan pembuat obat. Jenis sayuran yang satu ini mulai diminati oleh masyarakat Indonesia karena rasanya yang enak dan hampir menyamai kelezatan daging. Selain itu kandungan lemak dalam jamur yang lebih rendah daripada daging menjadikan jamur lebih sehat untuk dikonsumsi.

Kandungan protein yang dimiliki beberapa jenis jamur konsumsi lebih tinggi dibandingkan dengan jenis sayuran lainnya. Selain itu juga sebagai bahan makanan jamur mengandung banyak vitamin, seperti tiamin (vitamin B1), riboflavin (vitamin B2), niasin, vitamin $\mathrm{C}$, biotin, dan terkandung mineral seperti $\mathrm{K}, \mathrm{P}, \mathrm{Ca}, \mathrm{Cu}, \mathrm{Mg}$, serta beberapa mikro elemen lainnya. Senyawa seperti lentinan (penurun gula dan kolestrol darah), asam ganodernat dan ganodermin (antivirus, antikanker, pemusnah karsinogen) sangat bermanfaat dan memiliki khasiat sebagai obat.

Penggunaan lahan dalam budidaya jamur yang tidak harus luas, harga jual jamur yang tinggi, nilai gizi yang tinggi, serta waktu penanaman yang relatif singkat membuat perkembangan agribisnis jamur di Indonesia menjadi cukup pesat. Hal ini terlihat dari pembudidayaan jamur yang tersebar di seluruh wilayah Indonesia.

Provinsi Jawa Barat memiliki 26 daerah penghasil jamur yang terdiri dari 18 kabupaten dan 8 kota. dengan produktivitas penghasil jamur tertinggi adalah Jawa Barat; salah satunya di Kabupaten Bandung Barat (Jawa Barat dalam Angka, 2016).

Salah satu pelaku usahatani jamur yang berada di Kabupaten Bandung Barat adalah PT. Inti Jamur Raya yang terletak di Desa Cikole, Lembang. Di desa ini hanya terdapat dua perusahaan yang membudidayakan jamur yaitu PT. Inti Jamur Raya dan Pabrik Jamur Pondok Agro. Namun dalam perkembangannya, saat ini Pabrik Jamur Pondok Agro tidak lagi melakukan pembibitan jamur dan bibit jamur yang mereka pakai dipasok dari PT. Inti Jamur Raya.

PT. Inti Jamur Raya memproduksi beberapa jenis jamur diantaranya jamur tiram putih, jamur tiram coklat, jamur shiitake, jamur linzhi, jamur kuping dan jamur maitake. Kegiatan yang dilakukan meliputi pembuatan bibit jamur, budidaya jamur, pengolahan jamur, sortasi, pengemasan, pelabelan, serta penjualan jamur. Perusahaan melakukan budidaya jamur dengan menggunakan baglog. Baglog mengandung arti kantung ( $b a g)$ media berbentuk kayu gelondongan $(\log )$ atau dapat diartikan sebagai media tanam yang digunakan sebagai bahan produksi jamur yang akan diolah sehingga jamur dapat bertumbuh (Saryanti, 2017). Bahan yang digunakan untuk membuat baglog terdiri dari plastik transparan berukuran $21 \mathrm{~cm} \times 10 \mathrm{~cm}$ yang diisi dengan campuran serbuk kayu dan bahan formula.

PT. Inti Jamur Raya memiliki produktivitas jamur shiitake yang berfluktasi pada tahun 2015-2016. Hal itu menunjukkan produksi jamur shiitake di sektor on farm terindikasi adanya risiko produksi. Dengan penanganan yang selama ini dilakukan perusahaan, produktivitas jamur shiitake masih belum mencapai target yang ditetapkan, yakni 200-300 gr/baglog (PT. Inti Jamur Raya, 2016) Fluktuasi produktivitas tersebut dapat terus berlanjut apabila penyebab dan penanganannya tidak segera diselidiki. Oleh karena itu, untuk 
meminimalisasi penurunan produktivitas jamur shiitake maka perlu diketahui penyebab risiko yang terjadi untuk kemudian dapat segera

\section{dilakukan penanganannya}

\section{METODE PENELITIAN}

Teknik penelitian yang digunakan adalah studi kasus. Tempat penelitian di PT. Inti Jamur Raya, Desa Cikole, Kecamatan Lembang, Kabupaten Bandung Barat. Data terdiri dari data primer dan sekunder. Pengumpulan data primer dilakukan dengan cara observasi dan wawancara mendalam terhadap 4 informan PT. Inti Jamur Raya yang paling memahami teknis budidaya jamur shiitake yaitu: 1) pemimpin dan pemilik perusahaan; 2) kepala administrasi dan keuangan yang juga bertugas mengawasi kinerja setiap coordinator; 3) koordinator bahan baku; dan 4) koordinator kumbung. Sumber data sekunder berupa dokumen perusahaan, instansi pemerintah, laporan penelitian, buku teks, dan jurnal yang relevan dengan topik penelitian. Data dianalisis secara tabulasi dan dengan menggunakan Failure Mode and Effect Analysis (FMEA) untuk mengetahui penyebab prioritas terjadinya risiko produksi jamur shiitake.

Skala penilaian untuk FMEA disajikan pada Tabel 1, 2, dan Tabel 3.

Tabel 1.

Skala Tingkat Keparahan (Severity Rating Scale)

\begin{tabular}{|c|c|c|}
\hline Skala & Keterangan & \\
\hline 10 & $\begin{array}{l}\text { Penyebab kegagalan } \\
\text { menimbulkan efek } \\
\text { bahaya paling tinggi }\end{array}$ & $\begin{array}{l}\text { Dampak menyebabkan } \\
\text { produksi tidak dapat } \\
\text { digunakan }\end{array}$ \\
\hline 9 & $\begin{array}{l}\text { Penyebab kegagalan } \\
\text { menimbulkan efek } \\
\text { yang sangat tinggi }\end{array}$ & $\begin{array}{l}\text { Kegagalan produksi } \\
\text { meningkat di atas } 20 \%\end{array}$ \\
\hline 8 & $\begin{array}{l}\text { Penyebab kegagalan } \\
\text { menimbulkan efek } \\
\text { yang tinggi }\end{array}$ & $\begin{array}{l}\text { Kegagalan produksi } \\
\text { meningkat } 20 \%\end{array}$ \\
\hline 7 & $\begin{array}{l}\text { Penyebab kegagalan } \\
\text { menimbulkan efek } \\
\text { yang cukup tinggi }\end{array}$ & $\begin{array}{l}\text { Kegagalan produksi } \\
\text { meningkat lebih dari } \\
10 \%\end{array}$ \\
\hline 6 & $\begin{array}{l}\text { Penyebab kegagalan } \\
\text { menimbulkan efek } \\
\text { yang sedang }\end{array}$ & $\begin{array}{l}\text { Kegagalan produksi } \\
\text { meningkat } 10 \% \text {. }\end{array}$ \\
\hline 5 & $\begin{array}{l}\text { Penyebab kegagalan } \\
\text { menimbulkan efek } \\
\text { yang cukup rendah }\end{array}$ & $\begin{array}{l}\text { Kerusakan produksi } \\
\text { meningkat } 5 \%\end{array}$ \\
\hline 4 & $\begin{array}{l}\text { Penyebab kegagalan } \\
\text { menimbulkan efek } \\
\text { yang rendah }\end{array}$ & $\begin{array}{l}\text { Dampak pada ruang } \\
\text { lingkup kecil tapi mem- } \\
\text { butuhkan perubahan } \\
\text { secara internal }\end{array}$ \\
\hline 3 & $\begin{array}{l}\text { Penyebab kegagalan } \\
\text { menimbulkan efek } \\
\text { yang sangat rendah }\end{array}$ & Kegagalan produksi $5 \%$ \\
\hline
\end{tabular}

2 Penyebab kegagalan Dampak membawa menimbulkan efek perubahan tidak terlihat yang paling rendah

1 Penyebab kegagalan Dampak tidak signifikan tidak menimbulkan efek

Sumber : Carbone and Tippet, 2004

Tabel 2.

Skala Tingkat Kejadian (Occurance Rating Scale)

\begin{tabular}{|c|c|}
\hline Skala & Kejadian \\
\hline 10 & $\begin{array}{l}\text { Penyebab kegagalan yang paling sering } \\
\text { terjadi }\end{array}$ \\
\hline 9 & Penyebab kegagalan sangat sering terjadi \\
\hline 8 & Penyebab kegagalan yang sering terjadi \\
\hline 7 & $\begin{array}{l}\text { Penyebab kegagalan yang cukup sering } \\
\text { terjadi }\end{array}$ \\
\hline 6 & $\begin{array}{l}\text { Penyebab kegagalan yang terjadi pada } \\
\text { tingkat medium }\end{array}$ \\
\hline 5 & $\begin{array}{l}\text { Penyebab kegagalan yang cukup jarang } \\
\text { terjadi }\end{array}$ \\
\hline 4 & Penyebab kegagalan yang jarang terjadi \\
\hline 3 & $\begin{array}{l}\text { Penyebab kegagalan yang sangat jarang } \\
\text { terjadi }\end{array}$ \\
\hline 2 & Penyebab kegagalan paling jarang terjadi \\
\hline 1 & $\begin{array}{l}\text { Penyebab kegagalan hampir tidak pernah } \\
\text { terjadi }\end{array}$ \\
\hline
\end{tabular}

Sumber : Carbone and Tippet, 2004

Tabel 3.

Skala Kemampuan Mendeteksi (Detection Rating Scale)

\begin{tabular}{ll}
\hline Skala & Keterangan \\
\hline 10 & $\begin{array}{l}\text { Ketidakpastian mutlak, artinya penyebab } \\
\text { kegagalan tidak terdeteksi }\end{array}$ \\
9 & Penyebab kegagalan sangat sulit terdeteksi \\
8 & Penyebab kegagalan sulit terdeteksi \\
7 & Penyebab kegagalan terdeteksi rendah sekali \\
6 & Penyebab kegagalan terdeteksi cukup rendah \\
5 & Penyebab kegagalan terdeteksi rendah \\
4 & Penyebab kegagalan cukup terdeteksi \\
3 & Penyebab kegagalan terdeteksi tinggi \\
2 & Penyebab kegagalan terdeteksi sangat tinggi \\
1 & Penyebab kegagalan hampir pasti terdeteksi \\
\hline Sumber : Carbone and Tippet, 2004
\end{tabular}

Setelah pemberian rating, nilai Risk Priority Number (RPN) dan Risk Score Value (RSV) dihitung dengan rumus:

$$
\begin{aligned}
\mathrm{RPN}= & \text { skor kejadian }(\mathrm{Occ}) \times \text { skor } \\
& \text { keparahan }(\mathrm{Sev}) \times \text { skor deteksi } \\
& (\text { Det }) \\
\mathrm{RSV}= & \text { skor kejadian }(\mathrm{Occ}) \times \text { skor } \\
& \text { keparahan }(\mathrm{Sev})
\end{aligned}
$$

Semakin tinggi nilai RPN, semakin tinggi risiko kejadian tersebut. Selanjutnya dibuat diagram pareto RPN dan RSV untuk menganalisis risiko sehingga ditemukan 
penyebab yang merupakan kunci dari penyelesaian masalah dan perbandingan terhadap keseluruhan.

Setelah penyebab yang dominan masing-masing RPN dan RSV diketahui, selanjutnya dilakukan pengelompokan risiko menggunakan diagram pencar. Diagram pencar dibuat berdasarkan nilai kiritis dari RPN dan nilai kritis RSV. Suatu risiko dikategorikan sebagai risiko kritis jika memiliki nilai RPN dan $\mathrm{RSV} \geq$ nilai kritis. Untuk mendapatkan nilai kritis diperoleh dengan cara :

Nilai Kritis RPN $=($ Total RPN $) /($ Jumlah Penyebab Risiko) dan Nilai Kritis RSV = (Total RSV)/(Jumlah Penyebab Risiko). Nilai kritis dari RPN dan RSV akan membagi diagram menjadi empat bagian sebagai berikut:

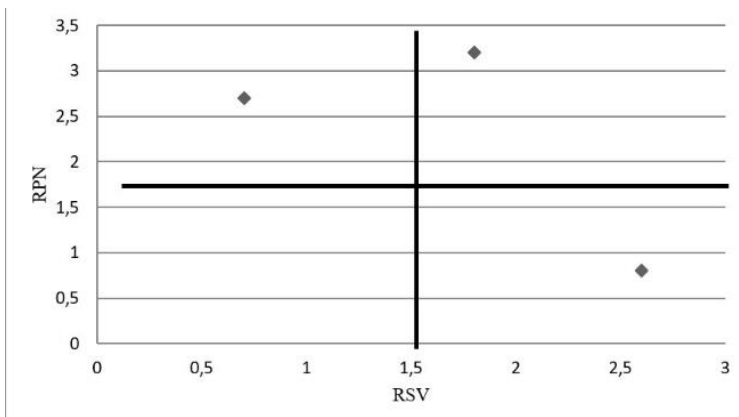

Sumber : Carbone and Tippet, 2004

Gambar 1. Diagram Pencar

- Daerah kanan atas: daerah dengan kategori risiko prioritas utama. Bila risiko-risiko pada daerah ini terjadi akan menyebabkan terancamnya pencapaian tujuan perusahaan.

- Daerah kiri atas: area dengan risiko yang rutin terjadi; tidak terlalu mengganggu pencapaian tujuan dan target perusahaan.

- Daerah kiri bawah: daerah dengan nilai RPN dan nilai RSV yang rendah. Hal ini berarti risiko-risiko yang muncul pada daerah ini cenderung diabaikan sehingga perusahaan tidak perlu mengalokasikan sumberdaya untuk menangani risiko tersebut.

- Daerah kanan bawah: risiko-risiko dalam daerah ini cukup jarang terjadi tetapi apabila sampai terjadi maka akan mengakibatkan tidak tercapainya tujuan dan target perusahaan.

\section{HASIL DAN PEMBAHASAN}

PT. Inti Jamur Raya memiliki 6 unit kumbung jamur, dan populasi tanaman kurang lebih 20.000 - 25.000 baglog jamur per kumbung (ruang untuk pertumbuhan jamur).

Jamur shiitake yang diproduksi perusahaan dijual ke ritel modern (Yogya, Setiabudhi Supermarket, Papaya Fresh Gallery), ke supplier (Bimandiri dan Fresco Verde Jakarta) serta dijual secara langsung. Selain dalam bentuk segar, perusahaan juga menjual jamur shiitake dalam keadaan kering dan dalam bentuk olahan makan berupa abon yang terbuat dari tangkai jamur shiitake.

Jamur dikemas dengan label IP Farms. Untuk produk segar, jamur dikemas dalam kemasan plastik transparan ukuran 100 gr dengan harga Rp 11.500/pack dan juga dijual seharga $100.000-150.000 / \mathrm{kg}$ secara curah. Sementara untuk produk kering, jamur dikemas dengan plastik ukuran 40 gr dengan harga Rp 20.000. Dan untuk jamur dalam bentuk abon dikemas dengan plastik ukuran 75 gr dengan harga Rp 35.000.

Produk yang dipasok untuk konsumen di wilayah Bandung, biasanya diambil secara langsung oleh pihak pembeli. Sementara untuk pemesanan di luar Bandung, pengiriman dilakukan oleh perusahaan dengan biaya yang ditanggung oleh pembeli. Permintaan produk oleh ritel modern maupun supplier disampaikan kepada pihak perusahaan sehari sebelum pengiriman.

\section{Identifikasi Penyebab Risiko}

Produksi. Berdasarkan wawancara mendalam dengan 4 informan, diidentifikasi penyebabpenyebab risiko yang terdapat dalam tahapan produksi jamur shiitake di PT. Inti Jamur Raya seperti ditunjukkan oleh Tabel 4.

Risiko pada tahap pembibitan adalah bibit tidak tumbuh yang disebabkan penggunaan bibit murni berumur lebih dari 1 tahun serta faktor kebersihan peralatan dan tenaga kerja.

Pada tahap penyiapan media tanam penyebab risiko yang teridentifikasi adalah serbuk kayu tidak dibolak-balik; hal ini menyebabkan pelapukan serbuk kayu.

Pengayakan serbuk kayu tidak merata, formula tidak sesuai takaran, dan pengadukan 
formula dengan serbuk kayu tidak merata. Itu semua menyebabkan bibit tidak tumbuh.

Selanjutnya, baglog tidak tertutup rapat; akibatnya mikroba pada serbuk kayu tidak mati seluruhnya sehingga proses pengukusan tidak sempurna.

Plastik media tanam berlubang; jadi hama masuk ke dalam baglog dan memakan miselium di dalamnya.

Tabel 4.

Tahapan Produksi dan Penyebab Risiko Produksi Jamur Shiitake

\begin{tabular}{|c|c|}
\hline Tahapan produksi & Penyebab risiko \\
\hline $\begin{array}{l}\text { Pembibitan: } \\
\text { 1.Pembuatan biakan } \\
\text { murni } \\
\text { 2.Pembuatan starter }\end{array}$ & $\begin{array}{l}\text { - Bibit murni } \\
\text { berumur lebih dari } \\
1 \text { tahun } \\
\text { - Pekerja tidak } \\
\text { mencuci tangan \& } \\
\text { kaki dengan } \\
\text { antiseptik } \\
\end{array}$ \\
\hline $\begin{array}{l}\text { Penyiapan media } \\
\text { tanam: } \\
\text { 1.Pengayakan } \\
\quad \text { serbuk kayu }\end{array}$ & $\begin{array}{l}\text { - Serbuk kayu tidak } \\
\text { dibolak-balik } \\
\text { - Pengayakan serbuk } \\
\text { kayu tidak merata }\end{array}$ \\
\hline $\begin{array}{l}\text { 2.Pengayakan } \\
\text { serbuk kayu } \\
\text { dengan campuran } \\
\text { formula } \\
\text { 3.Pengemasan } \\
\text { media tanam }\end{array}$ & $\begin{array}{l}\text { Formula tidak sesuai } \\
\text { takaran } \\
\text { Formula tidak tercampur } \\
\text { rata dengan serbuk kayu } \\
\text { Baglog tidak tertutup rapat } \\
\text { Plastik baglog berlubang }\end{array}$ \\
\hline Pengukusan: & \\
\hline Penanaman: & $\begin{array}{l}\text { Baglog terkena penyakit } \\
\text { Neurospora spp }\end{array}$ \\
\hline \multicolumn{2}{|l|}{ Inkubasi: } \\
\hline $\begin{array}{l}\text { Pemeliharaan: } \\
\text { 1.Penyiraman } \\
\text { 2.Pembukaan } \\
\text { plastik baglog }\end{array}$ & $\begin{array}{l}\text { - Baglog dibanting } \\
\text { saat dipindahkan ke } \\
\text { dalam kumbung } \\
\text { - Air penyiraman } \\
\text { terkontaminasi } \\
\text { - Penyiraman tidak } \\
\text { teratur } \\
\text { - Cara penyiraman } \\
\text { salah } \\
\text { - Baglog terkena } \\
\text { penyakit } \\
\text { Tricoderma spp } \\
\text { - Baglog terkena } \\
\text { penyakit Mucor } \\
\text { spp } \\
\text { - Baglog terkena } \\
\text { penyakit } \\
\text { Penicillium spp } \\
\text { - Baglog yang } \\
\text { terkena penyakit } \\
\text { tidak dibuang } \\
\text { - Cuaca ekstrim }\end{array}$ \\
\hline
\end{tabular}

\begin{tabular}{ll}
\hline & $\bullet$ Kumbung kotor \\
\hline Panen: & $\bullet$ Jamur yang \\
& dipanen jatuh ke \\
& lantai \\
& $\bullet$ Baglog terlambat \\
& dibuka \\
\hline
\end{tabular}

Pada tahap inkubasi, baglog terkena penyakit Neurospora spp sehingga tidak dapat digunakan lagi dan harus dibuang.

Pada tahap pemeliharaan, baglog dibanting saat dipindahkan ke dalam kumbung; hal itu menyebabkan baglog pecah dan tidak dapat digunakan lagi. Cara memegang baglog juga salah; akibatnya pertumbuhan miselium tidak merata.

Air penyiraman terkontaminasi; akibatnya merusak pertumbuhan miselium jamur. Teknik penyiraman juga salah; permukaan baglog jadi basah dan lembab. Penyiraman tidak teratur dan cuaca ekstrim; hal ini menyebabkan kualitas jamur menurun.

Kumbung kotor; akibatnya hama datang sehingga mengganggu pertumbuhan jamur. Penyakit Trichoderma spp, Mucor spp, Penicillium spp serta tidak dibuangnya baglog yang terkena penyakit menyebabkan baglog mati.

Pada tahapan panen, jamur yang dipanen jatuh ke lantai; akibatnya jamur kotor. Selain itu baglog terlambat dibuka; akibatnya jamur menjadi busuk.

\section{Pengukuran Penyebab Risiko Produksi.} Penyebab risiko yang telah teridentifikasi selanjutnya diberi nilai. Penilaian dilakukan dengan menggunakan Failure Mode and Effect Analysis (FMEA). Hasilnya disajikan pada Tabel 5. Dapat dilihat bahwa beberapa penyebab risiko mempunyai nilai RPN tinggi. Risk Priority Number (RPN) dihitung untuk mengetahui nilai prioritas risiko yang harus segera ditangani. Setelah diketahui penyebab risiko dengan RPN tertinggi, lalu penyebab risiko tersebut diplotkan pada diagram pareto, Gambar 2.

Tabel 5.

Penilaian Penyebab Risiko Produksi Jamur Shiitake di PT. Inti Jamur Raya.

\begin{tabular}{lllllll}
\hline No & PR & Sev & Occ & Det & RPN & RSV \\
\hline 1 & A & 7,25 & 2,50 & 1,25 & 23 & 18 \\
2 & B & 8,00 & 2,50 & 2,00 & 40 & 20 \\
3 & C & 5,00 & 4,25 & 3,75 & 80 & 21 \\
4 & D & 8,50 & 2,25 & 1,75 & 33 & 19
\end{tabular}




\begin{tabular}{lllllll}
5 & $\mathrm{E}$ & 9,00 & 1,25 & 1,00 & 11 & 11 \\
6 & $\mathrm{~F}$ & 7,00 & 2,50 & 4,50 & 79 & 18 \\
7 & $\mathrm{G}$ & 7,25 & 3,25 & 7,75 & 183 & 24 \\
8 & $\mathrm{H}$ & 9,50 & 5,75 & 7,00 & 382 & 55 \\
9 & $\mathrm{I}$ & 9,50 & 8,75 & 7,75 & 644 & 83 \\
10 & $\mathrm{~J}$ & 5,00 & 5,25 & 4,75 & 125 & 26 \\
11 & $\mathrm{~K}$ & 6,00 & 4,75 & 5,75 & 164 & 29 \\
12 & $\mathrm{~L}$ & 7,25 & 2,50 & 6,50 & 118 & 18 \\
13 & $\mathrm{M}$ & 7,25 & 5,75 & 5,50 & 229 & 42 \\
14 & $\mathrm{~N}$ & 5,50 & 5,00 & 6,25 & 172 & 28 \\
15 & $\mathrm{O}$ & 9,25 & 8,75 & 8,25 & 668 & 81 \\
16 & $\mathrm{P}$ & 9,25 & 7,75 & 8,25 & 591 & 72 \\
17 & $\mathrm{Q}$ & 8,75 & 8,00 & 7,75 & 543 & 70 \\
18 & $\mathrm{R}$ & 8,50 & 8,00 & 8,00 & 544 & 68 \\
19 & $\mathrm{~S}$ & 8,25 & 4,50 & 8,50 & 316 & 37 \\
20 & $\mathrm{~T}$ & 6,50 & 2,25 & 2,00 & 29 & 15 \\
21 & $\mathrm{U}$ & 4,50 & 3,75 & 3,50 & 59 & 17 \\
22 & $\mathrm{~V}$ & 8,50 & 6,25 & 6,75 & 359 & 53 \\
Total & & & & 5391 & 823 \\
Nilai kritis & & & & 245 & 37 \\
\hline
\end{tabular}

Sumber: Data diolah (2017)

Keterangan:

PR: Penyebab Risiko

Sev: Severity; Occ: Occurance; Det: Detection

A: Bibit murni berumur lebih dari 1 tahun

B: Pekerja tidak cuci tangan \&kaki dengan antiseptik

C: Serbuk kayu tidak dibolak-balik

D: Pengayakan serbuk tidak merata

E: Formula tidak sesuai takaran

F: Formula tidak tercampur rata dengan serbuk kayu

G: Plastik baglog berlubang

$\mathrm{H}$ : Baglog tidak tertutup rapat

I: Baglog terkena penyakit Neurospora spp.

$\mathrm{J}$ : Baglog dibanting saat dipindahkan ke kumbung

$\mathrm{K}$ : Cara memegang baglog salah

L: Air penyiraman terkontaminasi

M: Penyiraman tidak teratur

$\mathrm{N}$ : Cara penyiraman salah

O: Baglog terkena penyakit Trichoderma spp

P: Baglog terkena penyakit Penicillium spp

Q: Baglog terkena penyakit Mucor spp

$\mathrm{R}$ : Baglog yang terkena penyakit tidak dibuang

S: Cuaca ekstrim

T: Kumbung kotor

$\mathrm{U}$ : Jamur yang dipanen jatuh ke lantai

V: Baglog terlambat dibuka

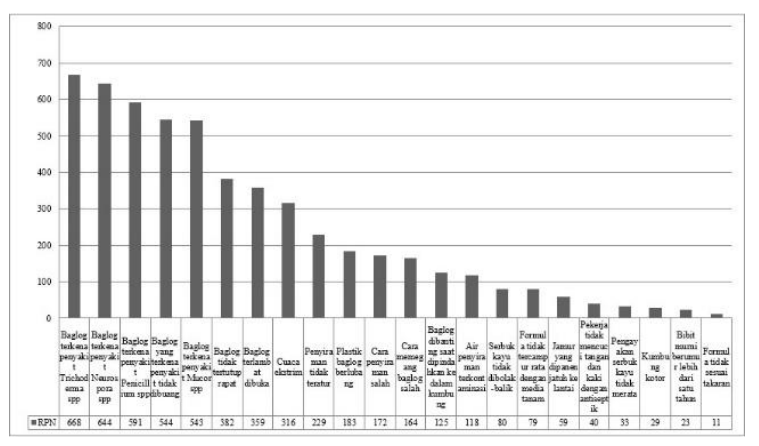

Sumber: Data Diolah (2017)

Gambar 2

\section{Diagram Pareto RPN}

Risk Score Value (RSV) dihitung untuk mengetahui nilai penyebab yang paling tinggi dari terjadinya suatu kegagalan. Diagram pareto RSV dapat dilihat pada Gambar 3.

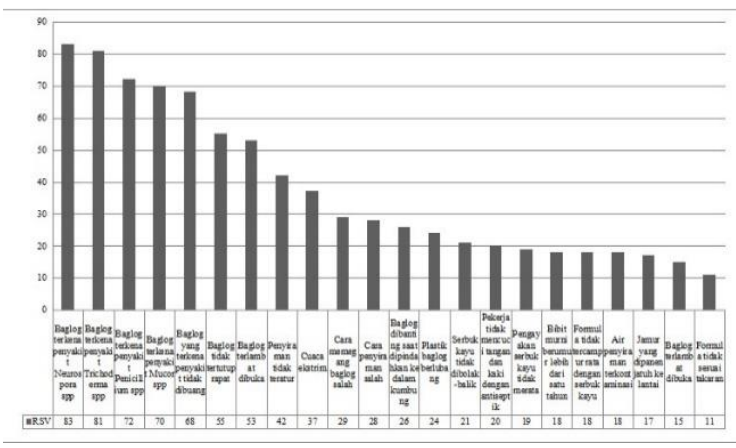

Sumber: Data Diolah (2017)

Gambar 3.

Diagram Pareto RSV

Setelah diagram pareto RPN dan RSV dibuat, lalu dihitung nilai kritisnya dengan membagi nilai total masing-masing dengan banyaknya penyebab (Tabel 5). Jadi, nilai kritis $\mathrm{RPN}=5391 / 22=245$ dan nilai kritis $\mathrm{RSV}=245 / 22=37$. Dengan diketahui nilai kritis RPN dan RSV, kemudian dibuat diagram pencarnya (scatter plot) dengan tujuan untuk mengetahui sebaran penyebab risiko berdasarkan nilai kritis (Gambar 4)

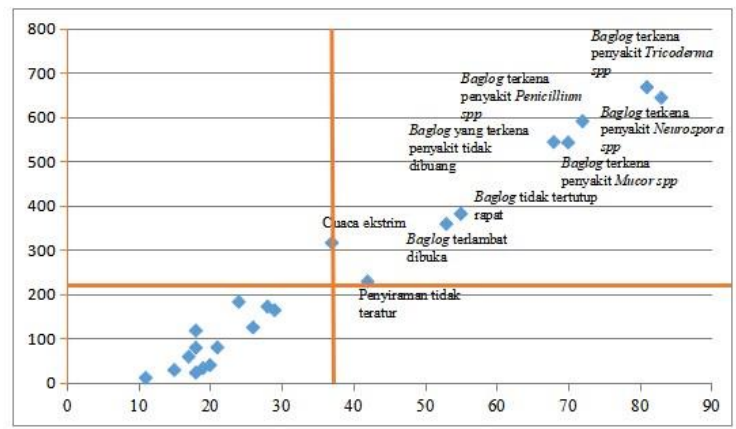

Sumber: Data Diolah (2017)

Gambar 4.

Pengelompokan Penyebab Risiko

Diagram pencar yang menunjukkan nilai kristis dari RPN dan RSV membagi diagram menjadi empat bagian. Pada bagian kanan atas adalah bagian dengan penyebab risiko yang paling mendesak dan perlu mendapat penanganan secepatnya karena mempunyai nilai RPN dan RSV paling tinggi. Penyebab risiko pada bagian ini terdiri dari baglog 
terkena penyakit Trichoderma spp, baglog terkena penyakit Neurospora spp, baglog terkena penyakit Penicillium spp, baglog terkena penyakit Mucor spp, baglog tidak tertutup rapat, baglog yang terkena penyakit tidak dibuang, baglog terlambat dibuka, cuaca ekstrim dan penyiraman tidak teratur. Penyebab risiko tertinggi menjadi prioritas utama untuk diberi penanganan.

\section{KESIMPULAN}

Penyebab risiko produksi jamur shiitake di PT. Inti Jamur Raya teridentifikasi sebanyak 22 penyebab, dimana 9 penyebab di antaranya merupakan penyebab prioritas. Kesembilan penyebab prioritas tersebut adalah: 1) baglog terkena penyakit Trichoderma spp; 2) baglog terkena penyakit Neurospora spp; 3) baglog terkena penyakit Penicillium spp; 4) baglog terkena penyakit Mucor spp; 5) baglog tidak tertutup rapat; 6) baglog yang terkena penyakit tidak dibuang; 7) baglog terlambat dibuka; 8) cuaca ekstrim; dan 9) penyiraman tidak teratur. Oleh karena itu PT. Inti Jamur Raya perlu melakukan sanitasi lokasi perkembangbiakan jamur shiitake dengan rutin; membersihkan rumput-rumput liar setiap kali rumput mulai tumbuh hingga tidak lagi terdapat rumput liar yang berada di sekitar kumbung.

Selanjutnya, penyebaran penyakit pada baglog sebaiknya dicegah dengan cara membakar baglog yang terkena penyakit untuk memutus siklus hidup pembawa penyakit tanaman.

Pengarahan dan evaluasi kerja secara rutin kepada para pekerja juga perlu dilakukan agar pekerja mempertahankan kemampuannya dan mengurangi kelalaian saat bekerja.

\section{DAFTAR PUSTAKA}

Badan Pusat Statistik. 2015. Produksi Jamur di Indonesia. (Diakses 16 Maret 2017)

Badan Pusat Statistik. 2016. Jawa Barat dalam Angka 2016. Badan Pusat Stasistik Provinsi Jawa Barat. (Diakses pada 16 Maret 2017)

Bureau of Waste Management. 2012. Best Practices for Environmental Protection in The Mushroom Farm Community. Pennsylvania: Department of Environmental Protection.
Bustaman, U, Magdalyn, A dan Kurniawati, F. 2015. Analisis Rumah Tangga Usaha Hortikultura di Indonesia. BPS. Jakarta

Carbone, T. A. And D. D Tippet. 2004. Project Risk Management using the project risk FMEA. "Engineering Management Journal", vol. 16, no.4.

Darmawi, H. 2010. Manajemen Risiko. Jakarta: Bumi Aksara.

Davis, M. Jeanine and Jean Harison. 2011. Producing Shiitake Mushroom: A Guide for Small Scale Outdoor Cultivation on Logs. North Carolina: North Carolina Cooperative Extension

Direktorat Jendral Hortikultura. 2015. Rencana Strategis Direktorat Jenderal Pertanian tahun 2015-2019. Kementrian Pertanian RI. (Diakses pada 25 Februari 2017)

Djefrianto, Ziko dan Suhartini. 2013. Analisa Risiko Kegagalan Proses Produksi Di PDAM Dengan Metode Fuzzy FMEA. Proceeding Industrial Design National Seminar Call For paper, Universitas Diponegoro Semarang, 25 September 2013, ISBN : 978-979-3514-66-6

Fahmi, Irham. 2015. Manajemen Risiko. Bandung: Alfabeta.

Hanif YH, Rukmi HS, dan Susanty S 2015. Perbaikan Kualitas Produk Keraton Luxury Di PT. X Dengan Menggunakan Metode Failure Mode And Effect Analysis (FMEA) Dan Fault Tree Analysis (FTA). Reka Integra, Jurnal Online Teknik Industri Itenas, Bandung. Vol 3, No 3 (2015)

Harwood, J, R. Heifner and K. Coble, J, Perry and A, Somwaru. 1999. Market and Trade Economics Division and Resource Economic Division, Economic Research Service. US Department of agriculture. Agricultural economic report no. 774.

Jaffee, Siegel, dan Colin Andrews. 2008. Rapid Agriculture Supply Chain Risk Assesment (RapAgRisk Assessment); Conceptual Framework and Guidelines for Application. Agriculture and Rural Development Department World Bank

Kasidi. 2010. Manajemen Risiko. Bogor: Ghalia Indonesia.

Ritchie, B., dan Brindley, C. (2007). An Emergency Framework for Supply Chain Risk Management and Performance Measurement. Journal of 
the Operational Research Society, Vol.58 No.11,hal. 1398-1411.

Saryanti, D. 2017. Perancangan Aplikasi Notifikasi Pembuatan Baglog Jamur Tiram. Jurnal Teknologi Informasi Vol 16, No 1 (2017)

Setiawan, Iwan. 2014. FMEA sebagai Alat Analisa Risiko Moda Kegagalan pada Magnetic Force Welding Machine Me27.1. No. 13/Tahun VII. ISSN 1979-2409

Sugiyono. 2012. Metode Penelitian Kuantatif, Kualitatif, dan $R \& D$. Bandung: Alfabeta.

Widyastuti, Netty. 2008. Jamur Shitake: Budidaya \& Pengolahan Si Jamur Penakluk Kanker. Jakarta: Lily Publisher. Wijaya, Sheila. 2014. The Secret of Jamur. Jakarta: FlashBooks.

Zeng, Tam, dan Y. Vivian. 2010 Integrating Safety, Environmental and Quality Risks for Project Management Using a FMEA Method.Economic of Engineering Decisions, 21 (1), hal 44-52

Zulkarnain, H. 2010. Dasar-Dasar Hortikultura. Jakarta: PT. Bumi Aksara. 
Vol. 2, No. 2, Desember 2017: 291-357 AGRICORE-Jurnal Agribisnis dan Sosial Ekonomi Pertanian 